\title{
FAILURE OF BOTH AZITHROMYCIN AND ANTIMONY TO TREAT CUTANEOUS LEISHMANIASIS IN MANAUS, AM, BRAZIL
}

\begin{abstract}
SUMMARY
A non-randomized controlled clinical trial was carried out in order to evaluate both azithromycin and antimony efficacy in cutaneous leishmaniasis in Manaus, AM, Brazil. Forty nine patients from both genders, aged 14 to 70 , with cutaneous ulcers for less than three months and a positive imprint for Leishmania spp. amastigotes were recruited into two groups. Group I (26 patients) received a daily-single oral dose of $500 \mathrm{mg}$ of azithromycin for 20 days and Group II (23 patients) received a daily-single intramuscular dose of $20 \mathrm{mg} / \mathrm{kg}$ of meglumine antimony, also for 20 days. Azithromycin cured three of 24 (12.5\%) patients on days 60,90 and 120 respectively whereas therapeutic failure was considered in 21 of $24(87.5 \%)$ cases. In group II, antimony cured eight of 19 (42.1\%) cases as follows: three on day 30, one each on day 60 and day 90, and three on day 120. Therapeutic failure occurred in 11 of 19 (57.9\%) individuals. The efficacy of antimony for leishmaniasis was better than azithromycin but analysis for the intention-to-treat response rate did not show statistical difference between them. Although azithromycin was better tolerated, it showed a very low efficacy to treat cutaneous leishmaniasis in Manaus.
\end{abstract}

KEYWORDS: Azithromycin; Antimony; Leishmaniasis; Leishmania spp.

\section{INTRODUCTION}

Leishmaniasis has been treated for decades with pentavalent antimony, pentamidine or amphotericin B but patients cure rate presents high variability depending on Leishmania spp., clinical picture and geographical location (SARAVIA et al, 1989; ROMERO et al., 2001).

Several studies have evaluated oral medicaments to treat cutaneous leishmaniasis caused by different Leishmania spp. without conclusive results (DOGRA \& SAXENA, 1996; ALRAJHI et al., 2002). Recently, patients with cutaneous leishmaniasis caused by L. (Viannia) panamensis in Colombia received miltefosine and presented cure rate of $91 \%$, whereas, in Guatemala, only $50 \%$ of cure was obtained in patients infected by L. (Viannia) brasiliensis (SOTO et al., 2004). The results in patients with visceral leishmaniasis in India also showed good efficacy (93\%) with this drug (SUNDAR et al., 2002).

Azithromycin has been used to treat infections caused mainly by intracellular microorganisms because of its tissular distribution within phagocytes and its long half life (PETERS et al., 1992; WILDFEUER et al., 1996). This drug has shown activity against Toxoplasma gondii, Plasmodium vivax and Cryptosporidium spp., among others (GIACOMETTI et al., 2000; PUKRITTAYAKAMEE et al., 2003).

In an experiment in-vitro and in-vivo model, azithromycin showed activity against Leishmania major (KROLEWIECKI et al., 2002). In an open trial in Brazil, it cured 16 out of 20 patients with cutaneous ulcers caused by Leishmania (Viannia) braziliensis, however, cure time, doses and cycles number presented high variability (PRATA et al., 2003). In the same location; three out of four old individuals with mucosal involvement presented clinical cure after several cycles with this drug (SILVA-VERGARA et al., 2004). Most recently, in an open study, none of 45 Syrian old-world leishmaniasis patients treated with azithromycin were cured (DAOUD \& BOUSHI, 2006). The aim of this trial was to compare both azithromycin and antimony efficacy in patients with cutaneous leishmaniasis.

\section{PATIENTS AND METHODS}

This trial was carried out in an endemic leishmaniasis area where high active transmission occurs due to deep ecosystem changes introduced in the last decades to enlarge agriculture borders, settlements alongside the roads and non-planned urbanization replacing native jungle. The patients recruited were referred by other clinicians selected among several hundred of local residents that were diagnosed during 2003 at the Fundação de Medicina Tropical do Amazonas, a leishmaniasis state reference center.

Sample size was estimated in 202 cases with Yates correction considering $30 \%$ and $50 \%$ of cure to antimony and azithromycin

(1) Curso de Pos-graduação em Medicina Tropical e Infectologia, Universidade Federal do Triângulo Mineiro, Caixa postal 118, 38001-970 Uberaba, MG, Brazil.

(2) Fundação de Medicina Tropical do Amazonas, Avenida Pedro Teixeira 25, 69040-000 Manaus, AM, Brazil.

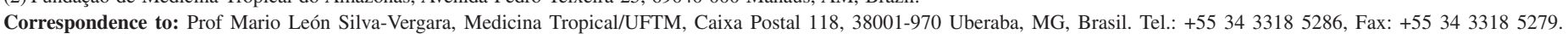
E-mail: marioleon.dip@mednet.com.br (M.L. Silva-Vergara). 


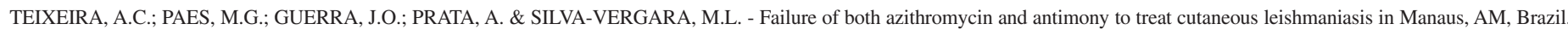
Rev. Inst. Med. trop. S. Paulo, 50(3): 157-160, 2008.

respectively. Criteria for enrollment were as follows: individuals of both genders, aged 14 to 70, presenting cutaneous ulcers for less than 12 weeks and a positive imprint for Leishmania spp. amastigotes. Exclusion criteria: patients with history of treatment for leishmaniasis in the last three months, difficulty to attend follow-up, mucosal or diffuse involvement, fever, previous macrolide or antimony allergy, pregnancy, diabetes mellitus, AIDS, vasculitis, use of corticosteroids or immunosuppressive drugs, renal, hepatic or cardiac diseases and/or engaged in another clinical trial.

The consent to enrollment was obtained prior to allocation. The patients were clinically examined and number, diameter and size of lesions were assessed. A intradermal test using standard antigen was performed in all according to procedure already described (MAYRINK et al., 1979).

Patients were allocated in two groups according to individual choice of treatment. Group I received a daily-single oral dose of $500 \mathrm{mg}$ of azithromycin for 20 days and Group II received a daily-single intramuscular dose of $20 \mathrm{mg} / \mathrm{kg}$ of meglumine antimony during the same period under supervision. Clinical follow-up was carried out every 30 days and all complaints, compliance and secondary effects were evaluated by spontaneous report and questionnaire.

Cure criteria were characterized by the whole epithelization of skin ulcers and the absence of erythema and/or inflammatory signs. Therapeutic failure was defined if lesions worsened on days 30, 60, 90 or 120 of follow-up despite an early good response.

Data analysis was performed using statistical for windows, 6.0 (Statsoft, Inc. USA). Shapiro-wilk test for normal distribution and Student's t test for independent samples, Mann-Withney for abnormal distributions and $\chi^{2}$ tests for comparing proportions. The project was approved by the ethical review board from Fundação de Medicina Tropical do Amazonas, Manaus, AM, Brazil.

\section{RESULTS}

From January to April 2003, forty nine patients with cutaneous leishmaniasis were recruited. Most of them were males under 35 years old. From these, 26 (53\%) received azithromycin (Group I) and 23 (47\%) received antimony (Group II). The main demographic and clinical characteristics of both groups were similar (Table 1).
Table 1

Epidemiological and clinical characteristics of 49 patients with cutaneous leishmaniasis in Manaus, AM, Brazil

\begin{tabular}{lccccc}
\hline Characteristics & \multicolumn{2}{c}{ Group I } & \multicolumn{2}{c}{ Group II } & \multirow{2}{*}{ value } \\
& $\mathrm{N}$ & $\%$ & $\mathrm{~N}$ & $\%$ & \\
\hline Age(years) & & & & & \\
$\quad 14-34$ & 61.5 & 16 & 69.5 & 0.54 \\
$\quad 10$ & 38.5 & 7 & 30.5 & \\
$\quad$ Gender & & & & & \\
$\quad$ Male & 5 & 80.8 & 21 & 91.3 & 0.20 \\
$\quad$ Female & & 19.2 & 2 & 7.7 & \\
Skin lesions(weeks) & 21 & 80.8 & 19 & 82.6 & 0.59 \\
$\quad<4$ & 4 & 15.4 & 4 & 17.4 & \\
$\quad$ 5-8 & 17 & 65.4 & 13 & 56.5 & 0.14 \\
Multiple ulcers & 18 & 69.3 & 12 & 52.1 & \\
Classical ulcer & 13 & 50.0 & 11 & 47.8 & 0.45 \\
Supraumbilical lesions & 15 & 57.7 & 7 & 30.4 & 0.05 \\
Ulcers with bacterial & & & & & \\
infection & 18 & 69.0 & 17 & 74.0 & 0.80 \\
Ulcer diameter < 2 cm & 21 & 84.0 & 20 & 91.0 & 0.43 \\
Positive intradermal test & & & & & \\
\hline
\end{tabular}

Clinical cure was noticed in three of $24(12.5 \%)$ cases of Group I on days 60, 90 and 120 respectively, whereas, 21 of $24(87.5 \%)$ patients presented therapeutic failure as follows: on day 30 of treatment, 19 worsened and two had improved but worsened on day 60 , then, they were all switched to antimony.

From Group II, eight of 19 (42.5\%) cases were cured as follows: three on day 30, one each on day 60 and day 90, and three on day 120 . The remaining 11 of $19(57.9 \%)$ improved on day 30, but seven of them worsened on day 60 and four on day 90 and then received another 20-day cycle of antimony. Two patients of the azithromycin group and four of the antimony group did not attend follow-up (Table 2).

In general, azithromycin was well tolerated, however, diarrhea, abdominal pain, dizziness, headache and nausea were reported by $60 \%$, $28 \%, 24 \%, 12 \%$ and $12 \%$ of them respectively but no patient interrupted the therapy because of these side effects On the other hand, patients receiving antimony, often complained of arthralgia and myalgia and

Table 2

Azithromycin efficacy in 49 patients with cutaneous leishmaniasis in Manaus, AM, Brazil

\begin{tabular}{|c|c|c|c|c|c|c|c|c|c|c|}
\hline \multirow[t]{2}{*}{ Follow-up/day } & \multicolumn{2}{|c|}{0} & \multicolumn{2}{|c|}{30} & \multicolumn{2}{|c|}{60} & \multicolumn{2}{|c|}{90} & \multicolumn{2}{|c|}{120} \\
\hline & I & II & I & II & I & II & I & II & I & II \\
\hline Allocation & 26 & 23 & - & - & - & - & - & - & - & - \\
\hline Improving & - & - & 5 & 16 & 2 & 4 & 1 & - & - & - \\
\hline Clinical cure & - & - & - & 3 & 1 & 1 & 1 & 1 & 1 & 3 \\
\hline Worsening & - & - & $19 *$ & - & $2 *$ & $7 * *$ & - & $4 * *$ & - & - \\
\hline Lost to follow-up & - & - & 2 & 4 & - & - & - & - & - & - \\
\hline
\end{tabular}

Group I: Azithromycin - Group II: Antimony; *: switched to Antimony; **: new treatment with Antimony. 
only four withdrew it due to the severity of these symptoms but their lesions cured.

Overall, azithromycin cured three of $24(12.5 \%)$ patients and antimony eight of $19(42.5 \%)\left(\chi^{2} 5.22, \mathrm{p}=0.035, \mathrm{OR}=5.33\right.$ and IC $95 \%$ 0.98-32.3). The analysis for the intention-to-treat response rate did not show statistical difference between the two groups.

\section{DISCUSSION}

Due to limited evidence about azithromycin activity against Leishmania spp., this trial compared it with antimony in 49 patients with cutaneous leishmaniasis from an area where L. (Viannia) guyanensis causes 97\% of infections (LAINSON \& SHAW, 1987; GRIMALDI et al., 1989).

Azithromycin cured only three of $24(12.5 \%)$ cases, similar to the results obtained in a pilot study in the same place (TEIXEIRA et al., 2007). In contrast, an open non-controlled study carried out in an endemic area where L. (Viannia) braziliensis prevails, azithromycin cured 16 of $20(85 \%)$ patients with cutaneous ulcers although the doses, treatment and cure time were variable (PRATA et al., 2003).

Spontaneous cure in leishmaniasis often occurs after six months and it was unlikely to have occurred in the three patients cured as the epithelization of their lesions began with azithromycin administration and were wholly cured up to four months, which suggests some drug effect and not spontaneous healing only. Besides, one of the inclusion criteria was ulcer with less than 12 weeks.

It has been suggested that early treatment of patients with leishmaniasis can not represent an advantage at least during the first four weeks when compared with the results observed in patients with long term lesions. Most individuals in this trial presented ulcers with less than four weeks which could have contributed to the poor outcome observed (ROCHA et al., 1999).

The proportion of patients that presented ulcers with evidence of bacterial infection was significantly higher in the azithromycin group $(57.7 \%$ vs $30.4 \%$ ) but, no difference related to response was observed between them. That may be explained by the selection bias during allocation. Besides, a former report has shown that bacterial secondary infection did not influence the healing process in cutaneous leishmaniasis (VERA et al., 2001).

The prolonged half life (2-6 days) and high intra-phagocyte concentration of azithromycin together with good tolerance and oral administration, are conditions highly desirable in leishmaniasis treatment. Nevertheless, its action mechanism is still unknown and it might be related to leishmanicide direct effect and/or immunomodulatory action (XU et al., 1996; IANARO et al., 2000).

Several reports have shown rate cure of 60 to $80 \%$ using antimony in patients with cutaneous lesions caused by L. (Viannia) braziliensis in Latin America. In contrast, in Manaus only $42.5 \%$ of the patients were cured with this drug similar to other results already published (OLIVEIRA-NETO et al., 1997; ROMERO et al., 2001). These data support the high variability in cure rate of this disease depending on
Leishmania spp., the clinical picture and the geographical region (SARAVIA et al., 1989; ROMERO et al., 2001; SOTO \& TOLEDO, 2007). Besides, drug resistance that would be a naturally acquired condition in leishmania, has been partially associated with poor response (GROGL et al., 1992).

Due to an impressive decrease of leishmaniasis cases at the time, the study was closed prematurely with a small size with 49 patients, different from the estimated 202 and just before the difference became statistically significant between the treatments. This fact, together with operational difficulties related to the follow-up and species definition, hinder a better evaluation of the results and their correlation with clinical and epidemiological factors, but evidenced a very low efficacy of azithromycin to treat cutaneous leishmaniasis in Manaus.

\section{RESUMO}

\section{Falha da azitromicina e do antimonial no tratamento da leishmaniose cutânea em Manaus, AM, Brasil}

Com o objetivo de avaliar a eficácia da azitromicina no tratamento da leishmaniose cutânea, foi realizado ensaio comparativo, em Manaus. Foram recrutados 49 pacientes de ambos os sexos, com idades entre 14 e 70 anos que apresentassem úlceras cutâneas com menos de três meses de evolução e que tivessem exame direto positivo para amastigotas de leishmânia. Estes pacientes foram alocados em dois grupos assim: Grupo I (26) recebeu uma dose diária de $500 \mathrm{mg}$ de azitromicina pela via oral durante 20 dias e o Grupo II, recebeu uma dose diária de $20 \mathrm{mg} / \mathrm{kg}$ de antimoniato de meglumina por via intramuscular, durante 20 dias. Do grupo da azitromicina, três (12,5\%) de 24 pacientes curaram 60, 90 e 120 dias, respectivamente, enquanto, em $21(87,5 \%)$ de 24 houve falha terapêutica. No grupo do antimonial, oito $(42,5 \%)$ de 19 pacientes curaram como segue: três no dia 30 , um no dia 60 , um no dia 90 e três no dia 120 . Contudo, em $11(57,9 \%)$ de 19 casos, houve falha terapêutica. A azitromicina foi menos eficaz do que o antimonial, embora, a análise da taxa de resposta por intenção de tratamento não mostrou diferença significativa, entre eles. A azitromicina foi melhor tolerada; porém, mostrou-se pouco eficaz no tratamento da leishmaniose cutânea, em Manaus.

\section{ACKNOWLEDGEMENTS}

The study was supported by CNPq and FUNASA. We are grateful to the kind assistance of the staff at Fundação de Medicina Tropical do Amazonas, Manaus, AM, and to Angela Azor and Maria Rita de Souza for technical assistance.

\section{REFERENCES}

1. ALRAJHI, A.A.; IBRAHIM, E.A.; DE VOL, E.B. et al. - Fluconazole for the treatment of cutaneous leishmaniasis caused by Leishmania major. New Engl. J. Med., 346: 891-895, 2002.

2. DAOUD, S. \& BOUSHI, L. - Azithromycin ineffective in the treatment of old-world cutaneous leishmaniasis. Int. J. Derm., 45: 1126-1128, 2006.

3. DOGRA, J. \& SAXENA, V.N. - Itraconazole and leishmaniasis: a randomised doubleblind trial in cutaneous disease. Int. J. Parasit., 26: 1413-1415, 1996. 


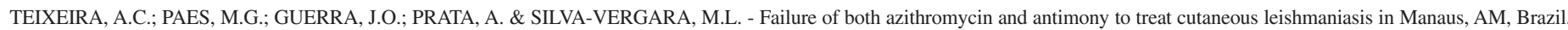
Rev. Inst. Med. trop. S. Paulo, 50(3): 157-160, 2008.

4. GIACOMETTI, A.; CIRIONI, O.; BARCHIESI, F; ANCARINI, F. \& SCALISE, G. Activity of nitazoxanide alone and in combination with azithromycin and rifabutin against Cryptosporidium parvum in cell culture. J. Antimicrob. Chemother., 45: 453-456, 2000

5. GRIMALDI Jr., G.; TESH, R.B. \& McMATTON-PRATT, D. - A review of geographical distribution and epidemiology of leishmaniasis in the New World. Amer. J. trop. Med. Hyg., 41: 687-725, 1989.

6. GROGL, M.; THOMASON, T.N. \& FRANKE, E.D. - Drug resistance in leishmaniasis: its implications in systemic chemotherapy of cutaneous and mucocutaneous disease. Amer. J. trop. Med. Hyg., 47: 117-126, 1992.

7. IANARO, A.; LALENTI, A.; MAFFIA, P. et al. - Antiinflammatory activity of macrolide antibiotics. J. Pharmacol. exp. Ther., 292: 156-163, 2000.

8. KROLEWIECKI, A.J.; LEON, S.; SCOTT, P. \& ABRAHAM, D. - Activity of azithromycin against Leishmania major in vitro and in vivo. Amer. J. trop. Med. Hyg., 67: 273 $277,2002$.

9. LAINSON, R. \& SHAW, J.J. - Evolution, classification and geographical distribution of leishmania. In: PETERS, W. \& KILLIK-KENDRICK, R., ed. The leishmaniasis in biology and epidemiology. London, Academic Press, 1987. p. 1-120.

10. MAYRINK, W.; WILLIAMS, P.; COELHO, M.B. et al. - Epidemiology of dermal leishmaniasis in the Rio Doce Valley, state of Minas Gerais, Brazil. Ann. trop. Med. Parasit., 73: 123-137, 1979.

11. OLIVEIRA-NETO, M.P.; SCHUBACH, A.; MATTOS, M.; GONÇALVES-COSTA, S.C. \& PIRMEZ, C. - A low-dose antimony treatment in 159 patients with American cutaneous leishmaniasis: extensive follow-up studies (up to 10 years). Amer. J. trop. Med. Hyg., 57: 651-655, 1997.

12. PETERS, D.H.; FRIEDEL, H.A. \& McTAVISH, D. - Azithromycin. A review of its antimicrobial activity, pharmacokinetic properties and clinical efficacy. Drugs, 44: 750-799, 1992

13. PRATA, A.; SILVA-VERGARA, M.L.; COSTA, L. et al. - Efficacy of azithromycin in the treatment of cutaneous leishmaniasis. Rev. Soc. bras. Med. trop., 36: 65-69, 2003.

14. PUKRITTAYAKAMEE, S.; CLEMENS, R.; CHANTRA, A. et al. - Therapeutic responses to antibacterial drugs in vivax malaria. Trans. roy. Soc. trop. Med. Hyg., 95: $524-$ 528,2003

15. ROCHA, P.N.; ALMEIDA, R.P.; BACELLAR, O. et al. - Down-regulation of Th1 type of response in early human American cutaneous leishmaniasis. J. infect. Dis., 180: 1731-1734, 1999
16. ROMERO, G.A.S.; GUERRA, M.V.F.G.; PAES, M.G. \& MACEDO, V.O. - Comparison of cutaneous leishmaniasis due to Leishmania (Viannia) braziliensis and L. (V.) guyanensis in Brazil: therapeutic response to meglumine antimoniate. Amer. J. trop. Med. Hyg., 65: 456-465, 2001.

17. SARAVIA, N.G.; VALDERRAMA, L.; LABRADA, M. et al. - The relationship of Leishmania braziliensis subspecies and immune response to disease expression in New World leishmaniasis. J. infect. Dis., 159: 725-735, 1989.

18. SILVA-VERGARA, M.L.; SILVA, L.A.; MANEIRA, F.R.Z.; SILVA, A.G. \& PRATA, A. - Azithromycin in the treatment of mucosal leishmaniasis. Rev. Inst. Med. trop. S. Paulo, 46: 175-177, 2004.

19. SOTO, J.; ARANA, B.A.; TOLEDO, J. et al. - Miltefosine for New World cutaneous leishmaniasis. Clin. infect. Dis., 38:1266-1272, 2004

20. SOTO, J.; TOLEDO, J.; GUTIERREZ, P. et al. - Treatment of American cutaneous leishmaniasis with miltefosine, an oral agent. Clin. infect. Dis., 33: 57-61, 2001

21. SOTO, J. \& TOLEDO, J.T. - Oral miltefosine to treat new world cutaneous leishmaniasis Lancet infect. Dis., 7: 7, 2007.

22. SUNDAR, S.; JHA, T.K.; THAKUR, C.P. et al. - Oral miltefosine for Indian visceral leishmaniasis. New. Engl. J. Med., 347: 1739-1746, 2002.

23. TEIXEIRA, A.C.; PAES, M.G.; GUERRA, J.O.; PRATA, A. \& SILVA-VERGARA, M.L. - Low efficacy of azithromycin to treat cutaneous leishmaniasis in Manaus, AM, Brazil. Rev. Inst. Med. trop. S. Paulo, 49: 235-238, 2007.

24. VERA, L.A.; SANTOS, J.B.; MACÊDO, V.O. et al. - Avaliação da influência da infecção bacteriana secundária na evolução da leishmaniose cutânea em Corte de Pedra, Bahia. Rev. Soc. bras. Med. trop., 34: 233-237, 2001.

25. WILDFEUER, A.; LAUFEN, H. \& ZIMMERMANN, T. - Uptake of azithromycin by various cells and its intracellular activity under in vivo conditions. Antimicrob. Agents Chemother., 40: 75-79, 1996.

26. XU, G.; FUJITA, J.; NEGAYAMA, K. et al. - Effect of macrolide antibiotics on macrophage functions. Microbiol. Immunol., 40: 473-479, 1996.

Received: 26 September 2007

Accepted: 2 April 2008 